\title{
Discursive structures and power relations in Covid-19 knowledge production
}

Mario Bisiada (1) ${ }^{1 凶}$

This article critically examines the discourse around the Covid-19 pandemic to investigate the widespread polarisation evident in social media debates. The model of epidemic psychology holds that initial adverse reactions to a new disease spread through linguistic interaction. The main argument is that the mediation of the pandemic through social media has fomented the effects of epidemic psychology in the reaction to the Covid-19 pandemic by providing continued access to commentary and linguistic interaction. This social interaction in the absence of any knowledge on the new disease can be seen as a discourse of knowledge production, conducted largely on social media. This view, coupled with a critical approach to the power relations inherent in all processes of knowledge production, provides an approach to understanding the dynamics of polarisation, which is, arguably, issue-related and not along common ideological lines of left and right. The paper critiques two discursive structures of exclusion, the terms science and conspiracy theory, which have characterised the knowledge production discourse of the Covid-19 pandemic on social media. As strategies of dialogic contraction, they are based on a hegemonic view of knowledge production and on the simplistic assumption of an emancipated position outside ideology. Such an approach, though well-intentioned, may ultimately undermine social movements of knowledge production and thus threaten the very values it aims to protect. Instead, the paper proposes a Foucauldian approach that problematises truth claims and scientificity as always ideological and that is aware of power as inherent to all knowledge production.

\footnotetext{
${ }^{1}$ Universitat Pompeu Fabra, Barcelona, Spain. ${ }^{凶}$ email: mario.bisiada@upf.edu
} 


\section{The first truly global, digitally mediated event}

\begin{abstract}
- he Covid-19 pandemic is the first truly global event:
Not the Black Plague, not the transatlantic slave trade nor the two World Wars, not the 9/11 terrorist attacks have affected everyone, on every continent, as instantly and intimately and acutely as the spread of coronavirus, uniting us as we fear and think and hope about the same thing. (Badhken, 2020)
\end{abstract}

While other events of historical magnitude had a global impact, they "were not experienced by the entire world at the same time" (Milanović, 2020) - though this experience takes a different form for each of us, in terms of both our personal reaction and that of the country we live in. What unites these personal experiences is that they have been largely digital because, apart from being the first truly global event, it is also "the first epidemic in history in which people around the world have been collectively expressing their thoughts and concerns on social media" (Aiello et al., 2021, p. 1). So our first global event is also the one "where we never met face-to-face in real-time with other people who lived through it" (Milanović, 2020).

Social media turned into the prime channel of the public sphere in quarantined societies, and a rigid and noxious polarisation evidently dominates the discourse (European Court of Human Rights, 2021; Yang, 2021). The question of why a crisis that should unite us in our communal struggle against a virus has produced such a divided society has put the spotlight on social media, which are still commonly assumed to be geared to create polarisation. The banning of @realdonaldtrump from Twitter may be read by future media scholars as to the beginning of an era of control of social media, as the end of Silicon Valley companies' innocence as mediators of discourse. Since the global communities' engagement in a fight against information disorder may produce other bans and regulations of free speech on public networks, the discussion of the role of social media as a public sphere will take important turns in the coming years.

In Rosenberg's $(1989$, p. 2) terms, as particular societies construct their characteristic responses following dramaturgic forms, epidemics are extraordinary opportunities to gain an "understanding of the relationship among ideology, social structure, and the construction of particular selves". To understand "our contemporary reaction to a traditional stimulus", we must distinguish between what is unique and what seems to be universal to pandemic responses (Rosenberg, 1989, p. 2). This article tries to take the first step towards this goal through a critical approach to the discourse on the Covid-19 pandemic. An aspect unique to this pandemic is that it has been mediated primarily by social media. How this has shaped the response will be subject to extensive study in years to come, and the large amount of language data this has produced will be of great interest to social media discourse analysts. I propose that the mediating role of social media has provided the opportunity to approach the pandemic through the mode of knowledge production practice that is already exhibited by social movements. Contests over this knowledge production, however, led to a polarisation that cannot be explained comprehensively by common partisan affiliations but that should be understood to be interpretative, that is, predominantly issue-related. I argue that this polarisation has caused, and is caused by, among other things, discursive structures of exclusion, specifically through the hegemonic use of terms such as conspiracy theories and science. The following section will begin this argument by introducing the model of epidemic psychology that I adopt to understand our reaction to the Covid-19 pandemic.

\section{Epidemic psychology and the virtual public sphere}

Strong (1990) proposes the "epidemic psychology" model to describe the early reaction to new fatal diseases. He comments on the "striking problems that large, fatal epidemics seem to present to social order; on the waves of fear, panic, stigma, moralising, and calls to action that seem to characterise the immediate reaction" and the "extraordinary emotional maelstrom which seems, at least for a time, to be beyond anyone's immediate control" (Strong, 1990, p. 249), descriptions that fit our experience in the first year of the Covid-19 pandemic quite well. Strong sees the capacity of language to enable coordinated action among large groups of people, our "shared intentionality" (Tomasello, 2008, p. 343), as the key factor in epidemic psychology, making human societies "complex and, though elaborately organised, still potentially subject to fundamental change, simultaneously massively ordered and extraordinarily fragile" (Strong, 1990, p. 256).

Most social action is based on routine: Strong (1990, p. 257) cites Alfred Schütz's idea that everyday life is "a matter neither of rationality nor irrationality, but of routine". Similarly, Berger and Luckmann (1966, p. 172) have argued that "the most important vehicle of reality-maintenance is casual conversation", which "can afford to be casual precisely because it refers to the routines of a taken-for-granted world. The loss of casualness signals a break in the routines and, at least potentially, a threat to the taken-forgranted reality" (Berger and Luckmann, 1966, p. 172). Such a threat to routine can lead to "epidemic psychology in which contagious waves of panic rip unpredictably through both individuals and the body politic, disrupting all manner of everyday practices, undermining faith in conventional authority" (Strong, 1990, p. 257). In sum,

the human origin of epidemic psychology lies not so much in our unruly passions as in the threat of epidemic disease to our everyday assumptions, in the potential fragility of human social structure and interaction, and in the huge diversity and elaboration of human thought, morality and technology; based as all of these are upon words rather than genes. (Strong, 1990, p. 258).

With language at the heart of epidemic psychology, the threshold at which epidemic psychology sets in may be lower in the digital age due to greater connectedness and thus exposure to language and conversation. The study of language use on social media is thus fundamental to understanding the social processes and transformations that will result from the Covid-19 pandemic. The Internet and social media are by now fundamentally important for all types of linguistic acts including casual conversation and coordinated social action. We produce and receive more language on a daily basis than ever (McCullock, 2019, p. 2). In Foucauldian terms, social media provides the environment of commentary that keep alive a large amount of discourses which would otherwise disappear (Foucault, 1981, pp. 56-57), thus creating the impression that particular knowledges are established. If we consider social media "important engines of context collapse, rather than enablers of ideological segregation" (Bruns, 2019, p. 99), it should come as no surprise that the symptoms of epidemic psychology described by Strong (1990) set in so quickly and transversally in our societies (see, e.g. Esses and Hamilton, 2021; Aiello et al., 2021).

Social media use has increased vastly during the Covid-19 pandemic (Nguyen et al., 2020), and it is the connectedness through social media that makes this pandemic unlike any other (Aiello et al., 2021; Madrigal, 2020; Tsao et al., 2021). The possibility to experience it in a socially distanced way is afforded to us only by our digitalised world. As Harari (2021) observes, "[i]n 1918, [...] if you ordered the entire population of a country to stay at home for several weeks, it would have resulted in 
economic ruin, social breakdown and mass starvation. In contrast, in 2020, [...] automation and the Internet made extended lockdowns viable, at least in developed countries". How viable they are in terms of long-term effects remains to be seen, and, as Harari (2021) rightfully notes, even this digital world could not function without "the crucial role that many low-paid professions play in maintaining human civilisation: nurses, sanitation workers, truck drivers, cashiers, delivery people". Given this fundamental importance of digital access, the \#StayHome narratives of lockdown life have been particularly developed-world, digitalised, middle class, childless narratives. But the key point is that "after 2020 , we know that life can go on even when an entire country is in physical lockdown" (Harari, 2021).

How will this new importance of social media affect society? Whether virtual public spaces also constitute a virtual public sphere has long been discussed (for an overview, see Bruns and Highfield, 2016). While using social media empowers users by broadcasting their opinions more widely, "the same anonymity and absence of face-to-face interaction that expands our freedom of expression online keeps us from assessing the impact and social value of our words" (Papacharissi, 2002, p. 16). In fact, this sense of empowerment may misrepresent the true impact of our opinions (Papacharissi, 2002, p. 17) and also of those held by others: Because a few vocal users can create a lot of activity, browsing social media may give us a distorted view of society, making it appear more polarised than it actually is.

A case in point is the (now deleted) Twitter thread that made Eric Feigl-Ding famous: He summarised a paper about the new coronavirus with the words "HOLY MOTHER OF GOD-the new coronavirus is a 3.8 !!!" and called this infectiousness "thermonuclear pandemic level bad" (24 January 2020). In a response thread on Twitter, science writer Ferris Jabr shows that FeiglDing's thread "missed essential context and contains numerous errors" and argues that his "claim that "we are now faced with the most virulent virus epidemic the world has ever seen' and that the new coronavirus is $8 \mathrm{x}$ as infectious as SARS is completely untrue" (https://twitter.com/ferrisjabr/status/1220963553911271424). Feigl-Ding's viral thread thus

exemplified a deep problem on Twitter: The most extreme statements can be far more amplified than more measured messages. In the information sphere, while public-health researchers are doing their best to distribute scientific evidence, viral Twitter threads, context-free videos, and even conspiracy theories are reaching far more people. (Madrigal, 2020)

Some argue, however, that it's exactly this recognition of constant evolution that should inform modern science, that FeiglDing has just understood how social media work and "committed the unpardonable sin of failing to act on Twitter like enough of a scientist-you know, terrified of getting something wrong, because science never does" (Science+Story, 2020). As social media come under increasing pressure through debates over misinformation, one task the pandemic sets us is to work towards a virtual public sphere that goes beyond the imagined communities (Anderson, 1983) or virtual spheres "consist[ing] of several spheres of counterpublics that have been excluded from mainstream political discourse, yet employ virtual communication to restructure the mainstream that ousted them" (Papacharissi, 2002, p. 21).

Most theorisations on the virtual public sphere consider it in conjunction with the non-virtual sphere. The new situation we face now is the temporary quasi-disappearance of physical interactions. As I have argued in this section, while epidemic psychology had been constrained in previous pandemics by the sheer absence of contact, it is now able to continue unchecked, simply because a lockdown no longer keeps us from conversing with the world. The public sphere has been forcibly moved into the virtual space, for a short yet decisive amount of time: Public shaming of "irresponsible" people, insults ("Covidiot"), dubious model predictions and all the other effects of epidemic psychology could be observed. This, as I argue in the following section, has made the Covid-19 pandemic a phenomenon of communal knowledge production practice.

\section{The Covid-19 pandemic as process of knowledge production} The Covid-19 pandemic is a unique phenomenon of knowledge production practice in the history of humanity because the phenomena of epidemic psychology described by Strong (1990) are for the first time mediated by a global network, that is, social media. The knowledge production in the Covid-19 pandemic resembles, in an accelerated form, that of climate change. Our first global event also gave us the opportunity to learn together, in real time, across the globe. Social media turn not only politics from a closed space into "a conversation that can be joined by outsiders" (Ausserhofer and Maireder, 2013, p. 306), but also science, by way of knowledge production practices. There has long been a discussion in the philosophy of science on how knowledge gets subsumed into "scientism", defined as "the conviction that we can no longer understand science as one form of possible knowledge, but rather must identify knowledge with science" (Habermas, 1972, p. 4). The Covid-19 pandemic has placed science along with its hegemonies in the spotlight of society, and it is thus informative to reflect on the relation between science and knowledge.

As a response to public fear, the Covid-19 pandemic has followed the model of epidemic psychology in generating an "exceptionally volatile intellectual state" (Strong, 1990, p. 254), as little is known about the new disease (Davey Smith et al., 2020) and there was uncertainty about whether "a new disease or a new outbreak is trivial or whether it is really something enormously important", leading to "collective disorientation" (Strong, 1990, p. 254). This volatile intellectual state and disorientation have created discourses of knowledge production (Casas-Cortés et al., 2008; Della Porta and Pavan, 2017; Pavan and Felicetti, 2019), defined as "practices through which local and highly personal experiences, rationalities, and competences get connected and coordinated within shared cognitive systems which, in turn, provide movements and their supporters with a common orientation for making claims and acting collectively" (Pavan and Felicetti, 2019, p. 3).

Such practices create what Foucault (1980) calls local, subjugated knowledges, defined as an "autonomous, non-centralised kind of theoretical production, one that is to say whose validity is not dependent on the approval of the established regimes of thought" (Foucault, 1980, p. 81). While such theoretical production consists of "local, discontinuous, disqualified, illegitimate knowledges", it does not constitute a right to ignorance or nonknowledge: it is opposed "not to the contents, methods or concepts of a science, but to the effects of the centralising powers which are linked to the institution and functioning of an organised scientific discourse" (Foucault, 1980, p. 84). More recently, Fischer (2000) has shown how local contextual knowledge by citizens can help solve complex social and environmental problems. One example of these from the current pandemic are mutual aid groups (Engler, 2020; Mahanty and Phillipps, 2020; Sitrin and Colectiva Sembrar, 2020). However, the often centralising, heavy-handed or even authoritarian responses of governments, coupled with blanket policies that reflected little trust in the intelligence or autonomy of its citizens, hindered such knowledge production movements. Citizens were delegated to a 
passive role while a selected group of experts led the response, which mirrors the dynamics experienced by environmental movements (Fischer, 2000, pp. 92-93).

A ready response to this volatile intellectual state tends to be that educated citizens should trust in science and condemn those who believe conspiracy theories, who spread fake news, who usher in an era of post-truth. Such a response, however, is often undergirded by a simplistic understanding of ideology, by the idea that we can and must somehow combat ideology and promote scientific truth through critical scrutiny of language and discourse in the media. Foucault criticised the usefulness of the notion of ideology for the fact that it "always stands in virtual opposition to something else which is supposed to count as truth" (Foucault, 1980, p. 180). Rather than exploring a knowable reality, scientific enquiry has been described as constructive practice, that is, "oriented toward 'making things work' successfully and embedded in a reality which is highly artificial and essentially selfcreated" (Knorr-Cetina, 1977, p. 670). In other words, assuming some kind of "false consciousness" within ideology presupposes the existence of a "consciousness which is not false (the position of critique)" (Mills, 2004, p. 29), but such a position does not exist: "All knowledge is determined by a combination of social, institutional and discursive pressures" (Mills, 2004, p. 30).

The dominating theoretical approaches to critical discourse studies hold that, through an awareness of linguistic/ideological oppression based on neo-Marxist or rationalist analysis, people are empowered to bring about social change and thus achieve emancipation (Hart and Cap, 2014, p. 2). While this is a useful approach to studying language and social change, Pennycook (2001, pp. 36-41) criticises such "emancipatory modernist" approaches as potentially patronising and argues that they lack the means to respond to the awareness of ideological oppression. Emancipatory modernist approaches to discourse are often grounded in a simplistic view of ideology juxtaposed with some "knowable reality" and hold the problematic notion that "scientific knowledge of reality can help us escape from the falsity of ideology" (Pennycook, 2001, p. 41), a rationale that is itself often used by populist agitators (Bruns, 2019, p. 114). Messianic attempts to help people see the light often fail, overlooking that many discourse practices aim to "explore others' reaction to one's identity and have it confirmed in interactions, including hostile reactions that confirm one's status as a critical outsider" (Krämer, 2017, p. 1302), thus cementing the very status one seeks to challenge into an emancipated position of its own. When studying epidemic psychology and the uncertain intellectual state it produces, it is thus more important than ever to remember that all language is political (Gee, 2011, p. 10), all knowledge production is ideological and there is no truth or knowledge outside ideology (Pennycook, 2001, p. 89).

As is the case with climate action, science's indeterminacy, its raising more questions than it could answer, has led to its politicisation (Fischer, 2000, p. 95). My argument in this section has been that, in the volatile intellectual state the Covid-19 pandemic has caused, the hegemonies of knowledge production, while always existing below the surface, have been made exceptionally visible. The restlessness of hypermediativity, fuelled by a constant generation and availability of data, allowed everyone to conduct "fact-based" statistical analyses and share them, around the clock. The fast exchange through social media and the way it empowers users to broadcast opinions and knowledge to wide audiences have caused a politicisation and polarisation of scientific debates (Clarke, 2020; Bhopal and Munro, 2021). In the context of the Covid-19 pandemic as a process of knowledge production, it is necessary to differentiate the concept of polarisation a bit further, as I will do in the next section.

\section{Interpretative polarisation}

In this paper, I understand polarisation as a dynamic phenomenon, driven by "interpretative" polarisation, "the process wherein different groups in a society contextualise a common topic in starkly different ways" so that "frames used by one camp are deemed unfounded, inappropriate, or illegitimate by other camps" (Kligler-Vilenchik et al., 2020, p. 2). Social media are so rooted in our daily lives that they receive attention from a range of disciplines, and many commentators still purport that social media "foster extreme viewpoints by design" (Bhopal and Munro, 2021) and are thus inherently geared to produce polarisation.

A range of evidence argues against this deterministic view, however. In a review of a range of studies, Tucker et al. (2018, pp. 15-16) argue that " $\mathrm{t}]$ he consumption of political information through social media increases cross-cutting exposure, which has a range of positive effects on civic engagement, political moderation, and the quality of democratic politics, but also facilitates the spread of misinformation". Bruns (2019) has cast doubt on Pariser's (2011) concept of the "filter bubble", and the popular idea that social bots on Twitter "pretend to be a human user and [are] operated by some sinister actor to manipulate public opinion" seems unfounded according to recent research (Gallwitz and Kreil, 2021). Frequent use of ever more available social media diversifies individuals' networks, which may alleviate concerns about echo chambers on social media (Lee et al., 2014), though may not necessarily "create more informed citizens" (Papacharissi, 2002, p. 15), or a public sphere as such: While social media use "may reduce ideological polarisation as a result of leading to higher cross-cutting exposure, it may simultaneously increase affective polarisation because of the negative nature of these interactions" (Tucker et al., 2018, p. 21), of which the Covid-19 pandemic has provided many.

In the absence of knowledge on the disease, the reactions to the Covid-19 pandemic subverted the established ideological standpoints. The range of ideological persuasions observed at antilockdown protests and the fact that liberal thinkers argue for closed borders while conservative thinkers question night-time curfews and police presence shows that the conflict cannot be thought along the usual partisan lines. Research on polarisation has argued for the recognition of various dimensions of opinion polarisation: Where new issues arise, people are prepared to deviate from their regular partisan or ideological direction (Wojcieszak and Rojas, 2011). Studies suggest that partisan/ ideological affiliation is not as directly influenced by knowledge as issue-related opinions:

$[\mathrm{K}]$ nowledge is found to predict the variance of two issuerelated measures of polarisation, whereas there is no such association between knowledge and partisan/ideological polarisation. This is consistent with previous research that the more knowledgeable are likely to move to more extreme issue positions by counter arguing claims incompatible with their political predisposition. (Lee et al., 2014, pp. 716-717)

People evaluate objects that they encounter frequently along different lines to rare but impactful objects: differing findings for party/ideology and issue-related polarisation suggest that the underlying mechanism of partisan and ideological polarisation is distinct from that of issue-related processes (Tucker et al., 2018, pp. 40-48). This recognition shows that studies or surveys linking attitudes towards the Covid-19 pandemic to partisan affiliations are not entirely informative.

In a study of how citizens evaluate arguments about contested issues, Taber and Lodge (2006) find that prior attitudes decisively guide how new information is processed: 
Far from the rational calculator portrayed in enlightenment prose and spatial equations, homo politicus would seem to be a creature of simple likes and prejudices that are quite resistant to change. [...] Skepticism is valuable and attitudes should have inertia. But skepticism becomes bias when it becomes unreasonably resistant to change and especially when it leads one to avoid information as with the confirmation bias. (Taber and Lodge, 2006, pp. 767-768)

The "boundary line between rational skepticism and irrational bias" (Taber and Lodge, 2006, p. 768) is a key issue in discussions about the Covid-19 pandemic, and one that can perhaps not be established in a normative way.

To address the question of why a newly arisen issue that could not be addressed by existing political schemes has polarised society so quickly, we may argue, then, that different contextualisations of the same issue have produced different evaluations in people (Kligler-Vilenchik et al., 2020). While people can generally process multiple frames and evaluate different angles, this ability may be hampered where "competing groups rely exclusively on contrasting frames and reject (or are unaware of) those frames underlying divergent preferences", which may lead to "contrasting interpretations that sustain irreconcilable positions". It is this configuration that, I argue, leads to interpretative polarisation, which may make "meaningful conversation between groups almost impossible" (Kligler-Vilenchik et al., 2020, p. 2) and reinforce political polarisation.

Examples of such contrasting interpretations abound. The term lockdown has had differing definitions in each country, which led to shadings such as hard/soft lockdown. The term new normal was perhaps meant to anchor hygiene measures in people's thoughts, but is seen by many as an attempt to normalise draconian restrictions and situations that are clearly anything but normal. The dichotomy of health vs economy is another example of how the same issue can be presented in different lights, depending on the angle one takes.

Interpretative polarisation can explain why partisan analysis does not apply to the Covid-19 pandemic as an extraordinary phenomenon whose epidemic psychology, as I have argued so far, made necessary new reflections, a process of knowledge production. The Covid-19 pandemic challenges existing ideological boundaries, so an analysis of its discourse requires an approach that goes beyond seeing ideology as a given structural object and instead analyses hegemonies and power struggles inherent in all discourses of knowledge production.

\section{Discursive structures of exclusion}

Exclusion through dialogic contraction. An oft-repeated charge in debates on the Covid-19 pandemic is that particular voices or opinions have been ignored or excluded from the debate, that particular things cannot be said. This is then countered by the reminder that there is free speech, that anyone can publish anything after all. Both positions forget that discourses are generally considered to be "principally organised around practices of exclusion" (Mills, 2004, p. 11): Any notion of what seems natural to say or what seems unsayable is the result of such exclusion practices, of "battles 'for truth"” where, in the words of Foucault, "by truth I do not mean 'the ensemble of truths which are to be discovered and accepted', but rather 'the ensemble of rules according to which the true and the false are separated and specific effects of power attached to the true"' (Foucault, 1980, p. 132).

Foucault (1981, pp. 52-54) proposes three procedures of exclusion: prohibition, the division of reason/madness and the opposition between true/false (the "will to truth"). The argument that nobody is excluded because everyone is free to publish anything misunderstands practices of discursive exclusion by reducing them to the first of those principles (prohibition) while ignoring the existence of the other two. Based on Bakhtin's concept of "centripetal-centrifugal struggle", Baxter (2011) argues that, as it is "difficult to presume that all discourses are equal in the play for meaning, [...] competing discourses are not equally legitimated. Some are centred (the centripetal) and others are marginalised (centrifugal). In the instance of monologue, all but a single totalising discourse is erased" (Baxter, 2011, p. 14). Thus, the struggles of exclusion are regular phenomena of hegemony in discourse, made visible through the extraordinary process of knowledge generation. The fact that free speech is constrained and certain things become dominant in discourses while others become unsayable is a product of competing power relations in a discourse (see Mills, 2004, p. 64). These power relations, as usual in Foucauldian thought, are not inherently negative or positive, but potentially dangerous if not questioned, which is the aim of this section.

In what follows, I investigate two discursive structures of exclusion via dialogic contraction that originate in the emancipatory modernist approach to ideology in discourse identified above: First, the reference to an abstract authority (the science) and second, accusations of conspiracy theories. I understand dialogic contraction with reference to Bakhtinian dialogism (for an introduction, see Robinson, 2011) as used in various theories of discourse analysis such as Appraisal Theory (Martin and White, 2005) and Relational Dialectics Theory. In the latter, discourses (defined roughly as systems of meaning or "voices") compete in discursive struggle, on a cline between monologic and idealised dialogic (Baxter, 2011). While in idealised dialogism all discourses are given equal weight, monologism consists of "a discursive playing field so unequal that all but one monologic, authoritative discourse is silenced" (Baxter, 2011, p. 9). This model is useful for analysing the discourse on the Covid-19 pandemic because it reflects the accusation that the public debate has increasingly become monologic, with the authoritative discourse of the respective political leaders and their close circles of experts in the dominant position.

One of the first demands on social media at the beginning of the pandemic was that people should be quiet and "let experts talk". These calls were meant to reduce noise in the discourse, a defence mechanism to the heated reactions in the networks, in line with early reactions of epidemic psychology. They were initial reactionary attempts to exclude voices from commenting on what was from the beginning a complex social crisis that concerns everyone. Attempts to restrict the discourse to "experts" only later crystallised into the two frequent formulas that we should follow the science and that we must combat conspiracy theories.

This simplistic binary choice juxtaposing the science/experts/ evidence with conspiracy theories/fake news is at the heart of the dialogic contraction in the Covid-19 pandemic. It makes it seem as though the only available positions are either to believe Covid19 to be a global threat that eclipses all other threats or to deny its existence altogether, thus mirroring labellings used in the climate debate, which "isolate, exclude, ignore, and dismiss claim-makers of all types from constructive dialogue" (Howarth and Sharman, 2015, p. 239).

These strategies of dialogic contraction work by appealing to taken-for-granted truths (science is good, populism is bad) and to an imagined neutral position outside ideology, power and discourse. This position is workable in routine debates, where challenges are either confined to academic circles or addressed by societies' "general politics of truth" (Foucault, 1980, p. 131). In an epistemologically disruptive event such as the Covid-19 pandemic, however, as I argue in this article, the role of science in the 
public enters the spotlight, epistemic psychology challenges our established routines, and discursive structures of dialogic contraction towards a monologic extreme rapidly translate into social polarisation.

Critical approaches to discourse that are conscious of and able to consider power relations as they emerge from discursive practice thus seem better suited to study our present situation. To study language with the aim of explaining power rather than just reveal it, we must show how power operates in discourses rather than how it is held by particular, pre-categorised actors or institutions (Pennycook, 2001, p. 93). As Katsambekis and Stavrakakis (2020) argue:

In many cases, understanding the policies of certain actors through the lens of 'populism' [...] and the vague notion of a 'populist threat to democracy', often adopted in typical anti-populist discourses, seems to be diverting attention from other imminent dangers to democracy, most importantly: nativism, nationalism, authoritarianism, racism. (Katsambekis and Stavrakakis, 2020, p. 7)

Having established discursive structures of exclusion as inherent to all discourse, I now discuss two strategies of dialogic contraction that I consider to be fundamental to the polarisation that we have seen in this pandemic and that let us answer why a global health crisis and the knowledge production that ensued, where we are all on the same side, has become such a polarising topic.

The science as legitimating authority. A central claim made by most leaders throughout the Covid-19 pandemic has been that they "follow the science" (Pérez-González, 2020b; Stevens, 2020; Pierce, 2021). In his first prime-time address to the nation on 11 March, Joe Biden said, "we know what we need to do to beat this virus. Tell the truth. Follow the scientists and the science". What is unclear about such statements is what exactly "the science" refers to. Sweden, under Anders Tegnell's advice, also "follows the science", and the rate of agreement of the Swedish scientific community, when asked whether scientific advice had been taken into account, does not differ from that reported for other countries (Rijs and Fenter, 2020). Yet the Swedish approach, generally described as at best "unorthodox", differs radically to that of many other countries, and mentioning "Sweden" in a current social network discussion is a safe way of being delegitimised as a reasonable discourse actor (Torjesen, 2021).

This suggests that the reductive notion of the science, like the similar formula the evidence (see Furedi, 2020), is defined based on particular principles of authority, established, though not overtly specified, by dominant discourse actors. It disclaims the multivoicedness, interdisciplinarity and plurality of processes of knowledge production (Knorr-Cetina, 1999) and serves as a discursive strategy of dialogic contraction, an expression of discursive hegemony: "The debate becomes polarised and binary: if the science says yes to face coverings, then challenging the orthodoxy or even questioning its universality becomes heretical" (Martin et al., 2020, p. 506).

Taylor (2010) conducts a corpus-assisted study of the use of the term the science in UK press articles between 1993 and 2008. Referring to Aristotle's model of rhetoric and argumentation, she argues that science, instead of being used as part of logos, providing logical proof, "is increasingly used as a part of ethos, that is, persuasion at the interpersonal level", projecting a particular stance towards the audience and appealing to an unspecified or unexplained authority, "making the writer's personal character appear more credible by enroling 'science' on their side of an argument" (Taylor, 2010, p. 222). This is especially the case where authors "refer to some unspecified, autonomous, authoritative entity" such as the science (Taylor, 2010, p. 236). These findings are echoed by Pérez-González's (2020a, p. 13) study of a corpus of a wide range of climate change blogs, where bloggers attempt to construct authoritative voices of consensus by using the the science formula.

While scientific discourse in general is rarely characterised by consensus, it is much less so in the context of the Covid-19 pandemic. A review of studies shows that a lot of research on the issue has been biased or of low quality (Raynaud et al., 2021). Critiques of bias in the acceptation and rejection of evidence have long existed (Stevens, 2007) and are echoed in a cross-country report on populism in the Covid-19 pandemic:

"Experts" are not neutral actors that will save liberal democracy from "bad populists". [...] [T] he pandemic has rather revealed the deeply political character of scientific input in critical junctures as well as the very political agency of experts themselves. [...] It becomes apparent then that exactly as populists do not form a coherent bloc in the pandemic, experts too cannot be treated as a unified front, thus the dichotomy "experts vs populists" is exposed as fundamentally flawed once more in the context of the ongoing crisis. (Katsambekis and Stavrakakis, 2020, pp. 7-8)

Many righteous approaches to the Covid-19 pandemic, but also to the climate emergency, succeed in identifying ideologically motivated harmful practices, but succumb to the emancipatory modernist lack of self-reflexivity on whether its messages, which are meant to convince the targeted audience, do not just patronise it, as discussed above. Populists will respond to this not by accepting that they are wrong, but by rejecting the entire frame of knowledge: "We'll probably also start to hear calls for climate lockdowns. I know, right now that sounds completely preposterous, but don't these kooky ideas always find a way to bleed into the mainstream? [...] Don't worry though, they're just following the science" (Miller, 2021).

It is understandable to want to reinforce a society that bases its actions on informed opinion, especially in the age of Trumpism. However, it is the very reductionism of an approach that makes an unspecified truth-claim to the science and disqualifies everything else as unreasonable that allows populist actors like Trump to gain power by turning the same simple strategy on its head. The postmodernist challenges of a simplified, messianic notion of the science remain valid. The formula represents a simplistic and hegemonic view of what "science" is and threatens to turn it into a buzzword of discursive exclusion and disciplining, undermining equal engagement in knowledge production.

Conspiracy theory as a sanctioning device. The second structure of exclusion I discuss is the term conspiracy theory. Husting and Orr (2007) critique this term as a metadiscursive "vocabulary of motive in struggles over the meaning of social and political worlds, events, and ideas" (2007, p. 132). In simple terms, its use signifies a discursive move of "going meta", that is, "elect[ing] to step back from the immediacy of a question to question the questioner's motives, or tone, or premises, or right to ask certain questions, or right to ask any questions at all" (Simons, 1994, p. 470). Invoking the label conspiracy theory thus has the function of "shifting the focus of discourse to reframe another's claims as unwarranted or unworthy of full consideration" (Husting and Orr, 2007, p. 129). While research has put into question whether applying the label has any negative effect on the targeted actor's beliefs (Wood, 2016), the accusation of conspiracy theory seeks to discursively expel actors from the community of reasonable 
interlocutors, thus "protecting certain decisions and people from question in arenas of political, cultural, and scholarly knowledge construction" (Husting and Orr, 2007, p. 130) by reverting the focus of attention onto the questioner.

This discursive structure is often used in "cultures of fear" that "generate new mechanisms of social control" (Husting and Orr, 2007, p. 128). Considering that many European countries are still in constant alert mode from terrorism, the description of such a culture fits the past year quite well:

fear and threat become the means for media, politicians, and corporations to sell commodities, buy votes, and justify policies reducing civil rights and promoting war (Altheide, 2000). As a mythos of consensus has turned into a mythos of fear, we would expect to find new interactional mechanisms to shield authority and legitimacy from challenge or accountability. (Husting and Orr, 2007, p. 130)

More recently, Husting (2018) identifies two problems with current academic and journalist discourse around conspiracy. First, a cognitive approach, which "attempts to diagnose traits like character and intelligence, intent on identifying hidden, usually individualised causes of constructing, believing in, and circulating conspiracy theories" (Husting, 2018, p. 111). By psychologising the subjects of its analysis in this way, "it misses the political work done by the labels themselves" and overstates their coherence to argue for their danger to society (Husting, 2018, p. 112). Husting argues that this cognitive analysis expresses a neoliberal responsibilisation of the individual in various ways to "follow expert advice to optimise well-being and health of body, mind, and polis" (Husting, 2018, p. 113). As citizens, we "regulate ourselves by regulating, judging, and contemning others, and keeping our own thoughts and styles of reason and emotion clear" (Husting, 2018, p. 123). The disputes over truth, falsity and conspiracy theories thus "serve to construct, circulate, and enact a 'well-tempered' citizen in liberal politics" (Husting, 2018, p. 113).

The second problem Husting (2018) identifies with current conspiracy theory discourse is its affective register. According to dominant analyses, conspiracy theorists "step out of the sphere of reason and logic, and enter the terrain of the emotional and the psychotic" (Husting, 2018, p. 117). Yet conspiracy discourse is itself "a form of emotional and political engagement driven by contempt and laced with anger and fear" by policing the boundaries of reasonable political doubt and theorising an "uncorrupted democratic sphere" (Husting, 2018, p. 117) outside ideology. By constructing conspiracy theories as threats to the order of the state and to the uncorrupted citizen, conspiracy theory discourse falls victim to the same pseudo-messianic discursive approach it seeks to unravel.

In a study of Wikipedia edits of the article on the German word for conspiracy theory, Verschwörungstheorie, Vogel (2018) argues that the term is not used with a descriptive, analytical function, but is part of an established metadiscursive accusatory, stigmatising and disciplinary pattern to sanction views from a position or epistemology outside the collectivism and the "sayable" in the ingroup, whose validity is assumed to be taken for granted (Vogel, 2018, p. 281). As Husting (2018, p. 120) says, "[o]nce the label 'conspiracy theory' sticks to someone, it impugns their intellectual and moral competence and relieves hearers of the need to consider the validity of her or his claims". The use of the term, thus, lacks a problematisation of one's own supposed neutrality. Its use is hegemonic, not analytical.

Vogel (2018) studies Wikipedia discourse specifically, but his observations are transferable to general social media discourse. And in the pandemic knowledge production, the epistemological conditions and power relations among participants within such knowledge production movements (Esteves, 2008) are comparable. Due to the shift of the public sphere into the digital as discussed above, most people will have experienced debates in online worlds along with everything this entails.

In a comprehensive survey of the usage of conspiracy theory, Butter (2018) writes that, while the Internet and social media have made conspiracy theories more visible and fast-moving, they are no more frequent or influential than they used to be because they are still regarded as "stigmatised knowledge". In the wake of the current surge of populism combined with the fragmentation of society through the Internet, Butter $(2018$, p. 18) argues, the fragmented public sphere and the different notions of truth condition the current debate in which some are afraid again of conspiracies while others are still worried about the fatal effects of conspiracy theories. The dialogic contraction we are arguably seeing can thus be traced to a particular constellation of fears for the public sphere combined with the fear of the pandemic.

In sum, value-laden terms such as conspiracy theory are attempts to exercise discursive power over others by excluding them from being reasonable participants in the debate, both in everyday interactions by users and in official government acts. Mechanisms that define limits of the sayable "weaken public spaces that are central for interaction, contest, and deliberation: the spaces where we define our world" (Husting and Orr, 2007, p. 147).

In this section, I have discussed two structures of exclusion by dialogic contraction: the science and conspiracy theory. These are common terms in everyday discourse, but, as I have shown, their appropriateness for academic study and debate is questionable due to their hegemonic nature and unreflected reference to accepted and sanctioned knowledge. This is not to say, of course, that we should endorse conspiracy theories or reject science. The aim is rather to become aware of how all types of knowledge are related to power. I am not interested here in evaluating the veracity of particular discourses on the Covid-19 pandemic (cf. Husting and Orr, 2007, p. 131), or even in whether conspiracy theories are dangerous or not, but in the mechanisms whereby one discourse becomes considered dominant and thus supported by financial and social capital whereas the other becomes confined to the margins of society (Mills, 2004, p. 17).

\section{Conclusion}

In this paper, I have adopted the model of epidemic psychology, which functions fundamentally through linguistic interaction, and argued that social media use has fomented its effects in the reaction to the Covid-19 pandemic by providing sustained access to commentary and linguistic interaction. I have suggested that this social interaction in a context of a volatile intellectual state can be seen as a discourse of knowledge production, conducted largely on social media. This view, along with the power relations it implies, provides an approach to understanding the dynamics of polarisation as interpretative, outside established partisan lines. To understand the polarisation better, I have discussed two discursive structures of exclusion, the terms the science and conspiracy theory, which have characterised the knowledge production discourse of the Covid-19 pandemic on social media. I have argued that these are strategies of dialogic contraction which are based on a hegemonic view of knowledge and a simplistic view of ideology based in the emancipatory modernist view of language that represents the currently dominant form of discourse analysis.

With this line of argument, I have intended to make sense of the Covid-19 pandemic discourse and take a step towards understanding the polarisation in our societies. As I have argued, this polarisation is due to discourse practices and not attributable to social media technology. The Covid-19 pandemic has forced us 
to reflect on many things, not just ourselves, but also the way we study society and (means of) communication. A great amount of data is being collected (see, e.g. Chen et al., 2020) and many studies will investigate the role of language and social media in the social transformation we are going to see in the coming years. I hope that the literature review conducted in this article has contributed some reflections on pertinent concepts and possible methodologies, or at least heuristics, for these future studies to consider.

From the perspective of discourse studies, I have endorsed the practice of Critical Applied Linguistics (Pennycook, 2001), which identifies both strengths and weaknesses of current approaches to discourse and seeks to improve on them by a greater foundation in critical theory and by a series of paradigmatic characteristics to problematise practice. Arguments are to be sought in texts, not in author profiles, so constructing corpora of texts harvested in "conspiracy theory" or "anti-vaxxer" forums or that consist of "fake news" means starting from a value position, a truth claim that can only confirm ideologies we already look for, but hardly explain their working in society. As Butter and Knight (2016, p. 23) argue, "the aim of producing empirical, value-neutral research on the phenomenon of 'conspiracy theory' is misguided, because the term itself is not value-neutral".

Categories such as "class", "gender", but also "identity" are often assumed to "exist prior to language", to be reflected in language use, when really they need to be explained themselves, with language being a part of this explanation (Cameron, 1995, p. 15). Like other conflicts, the polarisation in the wake of the Covid-19 pandemic has unveiled "the processes of norm-making and norm-breaking, bringing into the open the arguments that surround rules [...] and how unquestioned ('conventional') ways of behaving are implicitly understood by social actors" (Cameron, 1995, p. 17). It is this kind of processes that should be studied from a self-reflexive position that is aware of its own subjection to ideology and power relations.

A promising approach might be found in the Critical Disinformation Studies syllabus (Marwick et al., 2021), which argues, among other things, that fake news do not originate in extremism, but that "strategic disinformation and its cousin 'propaganda' are state and media industry practices with very long histories", so instead of "plac[ing] the responsibility on individuals to become better consumers of media", this approach seeks to "foreground questions of power, institutions, and economic, social, cultural, and technological structures as they shape disinformation". Research shows that greater public awareness of how science communication works increases the acceptance of scientific findings regardless of partisan ideologies (Weisberg et al., 2021).

The process of knowledge production on social media I envision in this paper in many ways resembles what is taking place in climate action and environmentalism (Pérez-González, 2020a). One might counter that the pandemic response cannot be called a social movement, but has been more of an emergency response to a problem that was always short-lived, and much more fast-paced than climate change, so is not perfectly comparable. But the knowledge production conducted on social media, and some of the movements born from this (see Sitrin and Colectiva Sembrar, 2020), provides a blueprint for environmentalism, a social movement that could benefit from the same kind of knowledgepractice. Some see the Covid-19 pandemic as a "test run" for the climate emergency, as there is hope "that the great mobilisations of state resources currently being unspooled to address Covid-19 prove the possibility of a comparable or greater mobilisation against ecological catastrophe" (Clover, 2021, p. S28). Nevertheless, the climate emergency has only recently been labelled thus and its perceived and mediatised urgency does not match that of Covid-19, though of course its destructive potential is far greater. The debate on science and knowledge in our societies and the ways in which these discourses are structured and mediated in social networks are thus of prime importance.

Received: 12 July 2021; Accepted: 12 October 2021;

Published online: 28 October 2021

\section{References}

Aiello LM, Quercia D, Zhou K, Constantinides M, Šćepanović S, Joglekar S (2021) How epidemic psychology works on social media: evolution of responses to the COVID-19 pandemic. Humanit Soc Sci Commun 8:179. https://doi.org/ 10.1057/s41599-021-00861-3

Altheide D (2000) Identity and the definition of the situation in a mass-mediated context. Symb Interact 23(1):1-27. https://doi.org/10.1525/si.2000.23.1.1

Anderson B (1983) Imagined communities: reflections on the origin and spread of nationalism. Verso, London

Ausserhofer J, Maireder A (2013) National politics on Twitter: structures and topics of a networked public sphere. Inf Commun Soc 16(3):291-314. https:// doi.org/10.1080/1369118X.2012.756050

Badhken A (2020) The pandemic, our common story. Granta. https:/granta.com/ the-pandemic-our-common-story/. Accessed 11 Oct 2021

Baxter LA (2011) Voicing relationships: a dialogic perspective. SAGE, London

Berger PL, Luckmann T (1966) The social construction of reality: a treatise in the sociology of knowledge. Penguin Books, London

Bhopal R, Munro APS (2021) Scholarly communications harmed by Covid-19. Br Med J 372:742. https://doi.org/10.1136/bmj.n742

Bruns A (2019) Are filter bubbles real? Polity, Cambridge

Bruns A, Highfield T (2016) Is Habermas on Twitter? Social media and the public sphere. In: Enli G, Bruns A, Skogerbo E, Larsson AO, Christensen C (eds) The Routledge companion to social media and politics. Routledge, Abingdon, pp. $56-73$

Butter M (2018) "Nichts ist, wie es scheint": Über Verschwörungstheorien. Suhrkamp, Berlin

Butter M, Knight P (2016) Bridging the great divide: conspiracy theory research for the 21st century. Diogenes 62(3-4):17-29. 10.1177/0392192116669289

Cameron D (1995) Verbal hygiene. Routledge, Abingdon

Casas-Cortés MI, Osterweil M, Powell DE (2008) Blurring boundaries: recognising knowledge-practices in the study of social movements. Anthropol Q 81(1):17-58. https://doi.org/10.1353/anq.2008.0006

Chen E, Lerman K, Ferrara E (2020) Tracking social media discourse about the COVID-19 pandemic: development of a public coronavirus twitter data set. JMIR Public Health Surveill 6(2):e19273. https://doi.org/10.2196/19273

Clarke L (2020) Why scientists fear the "toxic" Covid-19 debate. New Statesman. https://www.newstatesman.com/science-tech/coronavirus/2020/10/whyscientists-fear-toxic-covid-19-debate. Accessed 11 Oct 2021

Clover J (2021) The rise and fall of biopolitics: a response to Bruno Latour. Crit Inq 47(S2):S28-S32. https://doi.org/10.1086/711429

Davey Smith G, Blastland M, Munafò M (2020) Covid-19's known unknowns. Br Med J 371:m3979. https://doi.org/10.1136/bmj.m3979

Della Porta D, Pavan E (2017) Repertoires of knowledge practices: social movements in times of crisis. Qual Res Organ Manag 12(4):297-314. https:// doi.org/10.1108/QROM-01-2017-1483

Engler P (2020) Coronavirus is a historic trigger event-and it needs a movement to respond. Waging Nonviolence. https://wagingnonviolence.org/2020/03/ coronavirus-historic-trigger-event-needs-movement-response/. Accessed 11 Oct 2021

Esses VM, Hamilton LK (2021) Xenophobia and anti-immigrant attitudes in the time of COVID-19. Group Process Intergroup Relat 24(2):253-59. https:// doi.org/10.1177/1368430220983470

Esteves AM (2008) Processes of knowledge production in social movements as multi-level power dynamics. Sociol Compass 2(6):1934-1953. https://doi.org/ $10.1111 / \mathrm{j} .1751-9020.2008 .00146 . \mathrm{x}$

European Court of Human Rights (2021) ECHR President: Polarisation and Covid19 threaten difficult times ahead. Council of Europe. https://www.coe.int/en/ web/portal/-/echr-president-polarisation-and-covid-19-threaten-difficulttimes-ahead. Accessed 11 Oct 2021

Fischer F (2000) Citizens, experts, and the environment: the politics of local knowledge. Duke University Press, Durham

Foucault M (1980) Truth and power. In: Gordon C (ed) Power/knowledge: selected interviews and other writings 1972-1977. The Harvester Press, Brighton, pp. $107-133$

Foucault M (1981) The order of discourse. In: Young R (ed) Untying the text: a post-structuralist reader. Routledge, Abingdon, pp. 48-78 
Furedi F (2020) Why the government should not always "follow the science". Spiked. https://www.spiked-online.com/2020/05/20/why-the-governmentshould-not-always-follow-the-science/. Accessed 11 Oct 2021

Gallwitz F, Kreil M (2021) The rise and fall of "Social Bot" research. SSRN. https:// ssrn.com/abstract=3814191. Accessed 11 Oct 2021

Gee JP (2011) An introduction to discourse analysis: theory and method, 3rd edn. Routledge, Abingdon

Habermas J (1972) Knowledge and human interests (trans: Shapiro JJ). Heineman, London

Harari YN (2021) Lessons from a year of Covid. Financial Times. https:// www.ft.com/content/f1b30f2c-84aa-4595-84f2-7816796d6841. Accessed 11 Oct 2021.

Hart C, Cap P (2014) Introduction. In: Hart C, Cap P (eds) Contemporary critical discourse studies. Bloomsbury, London, p 1-16

Howarth CC, Sharman AG (2015) Labeling opinions in the climate debate: a critical review. WIREs Clim Change 6(2):239-254. https://doi.org/10.1002/ wcc. 332

Husting G (2018) Governing with feeling: conspiracy theories, contempt, and affective governmentality. In: Dentith MRX (ed) Taking conspiracy theories seriously. Rowman \& Littlefield International, Lanham, pp. 109-123

Husting G, Orr M (2007) Dangerous machinery: "Conspiracy Theorist" as a transpersonal strategy of exclusion. Symb Interact 30(2):127-150. https:// doi.org/10.1525/si.2007.30.2.127

Katsambekis G, Stavrakakis Y (2020) Populism and the pandemic: introduction and preliminary findings. In: Katsambekis G, Stavrakakis Y (eds) Populism and the pandemic: a collaborative report. POPULISMUS, Thessaloniki, pp. 3-9

Kligler-Vilenchik N, Baden C, Yarchi M (2020) Interpretative polarisation across platforms: How political disagreement developes over time on Facebook, Twitter, and WhatsApp. Soc Media+Soc 6(3):1-13. https://doi.org/10.1177/ 2056305120944393

Knorr-Cetina K (1977) Producing and reproducing knowledge: descriptive or constructive? Soc Sci Inf 16(6):669-96

Knorr-Cetina K (1999) Epistemic cultures: how the sciences make knowledge. Harvard University Press, Cambridge

Krämer B (2017) Populist online practices: the function of the Internet in rightwing populism. Inf Commun Soc 20(9):1293-1309. https://doi.org/10.1080/ 1369118X.2017.1328520

Lee JK, Choi J, Kim C, Kim Y (2014) Social media, network heterogeneity, and opinion polarisation. J Commun 64(4):702-722. https://doi.org/10.1111/ jcom. 12077

Madrigal AC (2020) How to misinform yourself about the coronavirus. The Atlantic. https://www.theatlantic.com/technology/archive/2020/01/chinacoronavirus-twitter/605644/. Accessed 11 Oct 2021

Mahanty S, Phillipps N (2020) The community-led movement creating hope in the time of coronavirus. The Conversation. https://theconversation.com/thecommunity-led-movement-creating-hope-in-the-time-of-coronavirus134391.

Martin GP, Hanna E, McCartney M, Dingwall R (2020) Science, society, and policy in the face of uncertainty: Reflections on the debate around face coverings for the public during COVID-19. Crit Public Health 30(5):501-508. https:// doi.org/10.1080/09581596.2020.1797997

Martin JR, White PRR (2005) The language of evaluation: appraisal in English. Palgrave Macmillan, Basingstoke

Marwick A, Kuo R, Cameron SJ, Weigel M (2021) Critical disinformation studies: a syllabus. Center for Information, Technology, and Public Life. https:// citap.unc.edu/research/critical-disinfo/. Accessed 11 Oct 2021

McCullock G (2019) Because Internet: understanding the new rules of language. Riverhead Books, New York

Milanović B (2020) The first global event in the history of humankind. IPS. https:// www.ips-journal.eu/topics/democracy/the-first-global-event-in-the-historyof-humankind-4848/. Accessed 11 Oct 2021

Miller SL (2021) Are you ready for the climate lockdowns? It's only a matter of time. The Spectator. https://spectatorworld.com/topic/ready-climatelockdowns-environment/. Accessed 11 Oct 2021

Mills S (2004) Discourse, 2nd edn. Routledge, Abingdon

Nguyen MH, Gruber J, Fuchs J, Marler W, Hunsaker A, Hargittai E (2020) Changes in digital communication during the COVID-19 global pandemic: implications for digital inequality and future research. Soc Media+Soc 6(3) https://doi.org/10.1177/2056305120948255

Papacharissi Z (2002) The virtual sphere: the Internet as a public sphere. New Media Soc 4(1):9-27. https://doi.org/10.1177/14614440222226244

Pariser E (2011) The filter bubble: what the internet is hiding from you. Penguin Press, London

Pavan E, Felicetti A (2019) Digital media and knowledge production within social movements: insights from the transition movement in Italy. Soc Media+Soc 5(4):1-12. https://doi.org/10.1177/2056305119889671
Pennycook A (2001) Critical applied linguistics: a critical introduction. Lawrence Erlbaum Associates, Mahwah

Pérez-González L (2020a) "Is climate science taking over the science?" A corpusbased study of competing stances on bias, dogma and expertise in the blogosphere. Humanit Soc Sci Commun 7:92. https://doi.org/10.1057/s41599$020-00582-\mathrm{z}$

Pérez-González L (2020b) "The government is following the science": why is the translation of evidence into policy generating so much controversy? London School of Economics Blogs. https://blogs.lse.ac.uk/impactofsocialsciences/ 2020/11/12/the-government-is-following-the-science-why-is-the-translationof-evidence-into-policy-generating-so-much-controversy/. Accessed $11 \mathrm{Oct}$ 2021

Pierce K (2021) "Follow the science" and other principles of Biden's pandemic response plan. The HUB. https://hub.jhu.edu/2021/01/15/biden-covidresponse-hopkins-alums/. Accessed 11 Oct 2021

Raynaud M, Zhang H, Louis K, Goutaudier V, Wang J, Dubourg Q, Wei Y, Demir Z, Debiais C, Aubert O, Bouatou Y, Lefaucheur C, Jabre P, Liu L, Wang C, Jouven X, Reese P, Empana JP, Loupy A (2021) Covid-19-related medical research: a meta-research and critical appraisal. BMC Med Res Methodol 21(1):1-11. 10.1186/s12874-020-01190-w

Rijs C, Fenter F (2020) The academic response to COVID-19. Front Public Health 8:621563. https://doi.org/10.3389/fpubh.2020.621563

Robinson A (2011) Bakhtin: dialogism, polyphony and heteroglossia. Ceasefire. https://ceasefiremagazine.co.uk/in-theory-bakhtin-1/. Accessed 11 Oct 2021

Rosenberg CE (1989) What is an epidemic? AIDS in historical perspective. Daedalus 118(2):1-17

Science+Story (2020) Eric Feigl-Ding is good at Twitter. Sci+Story. https:// scienceplusstory.com/eric-feigl-ding-is-good-at-twitter/. Accessed 11 Oct 2021

Simons H (1994) "Going meta": definition and political applications. Q J Speech 80(4):468-481. https://doi.org/10.1080/00335639409384088

Sitrin M, Colectiva Sembrar (2020) Pandemic solidarity. Pluto Books, London

Stevens A (2007) Survival of the ideas that fit: an evolutionary analogy for the use of evidence in policy. Soc Policy Soc 6(1):25-35. https://doi.org/10.1017/ S1474746406003319

Stevens A (2020) Governments cannot just "follow the science" on COVID-19. Nat Hum Behav 4:560. https://doi.org/10.1038/s41562-020-0894-x

Strong P (1990) Epidemic psychology: a model. Sociol Health Illn 12(3):249-259. https://doi.org/10.1111/1467-9566.ep11347150

Taber CS, Lodge M (2006) Motivated skepticism in the evaluation of political beliefs. Am J Political Sci 50(3):755-769. https://doi.org/10.1111/j.15405907.2006.00214.x

Taylor C (2010) Science in the news: a diachronic perspective. Corpora 5(2):221-250. https://doi.org/10.3366/cor.2010.0106

Tomasello M (2008) Origins of human communication. MIT Press, Cambridge

Torjesen I (2021) Covid-19: Sweden vows greater protection for academics as researcher quits after aggressive social media attack. Br Med J 372:489. https://doi.org/10.1136/bmj.n489

Tsao SF, Chen H, Tisseverasinghe T, Yang Y, Li L, Butt ZA (2021) What social media told us in the time of COVID-19: a scoping review. Lancet Digit Health 3(3):e175-e194. https://doi.org/10.1016/S2589-7500(20)30315-0

Tucker JA, Guess A, Barberá P, Vaccari C, Siegel A, Sanovich S, Stukal D, Nyhan B (2018) Social media, political polarisation, and political disinformation: a review of the scientific literature. SSRN. https://ssrn.com/abstract=3144139. Accessed 11 Oct 2021

Vogel F (2018) Jenseits des Sagbaren: Zum stigmatisierenden und ausgrenzenden Gebrauch des Ausdrucks Verschwörungstheorie in der deutschsprachigen Wikipedia. Aptum: Z Sprachkrit Sprachkult 14(3):259-287

Weisberg DS, Landrum AR, Hamilton J, Weisberg M (2021) Knowledge about the nature of science increases public acceptance of science regardless of identity factors. Public Underst Sci 30(2):120-138. https://doi.org/10.1177/ 0963662520977700

Wojcieszak M, Rojas H (2011) Correlates of party, ideology and issue based extremity in an era of egocentric publics. Int J Press/Politics 16(4):488-507. https://doi.org/10.1177/1940161211418226

Wood MJ (2016) Some dare call it conspiracy: Labeling something a conspiracy theory does not reduce belief in it. Political Psychol 37(5):695-705. https:// doi.org/10.1111/pops.12285

Yang A (2021) Politicisation and polarisation of Covid-19. Frontiers. https:// frontiersmag.wustl.edu/2021/01/10/politicization-and-polarization-of-covid19/. Accessed 11 Oct 2021

\section{Acknowledgements}

This work is part of the project Frames and narratives of translation and of migration in Europe, funded by the Spanish Ministry for Science, Innovation and Universities (MCIU) and the Agencia Estatal de Investigación (AEI), with grant number PID2019-107971GA-I00. 


\section{Competing interests}

The author declares no competing interests.

\section{Additional information}

Correspondence and requests for materials should be addressed to Mario Bisiada.

Reprints and permission information is available at http://www.nature.com/reprints

Publisher's note Springer Nature remains neutral with regard to jurisdictional claims in published maps and institutional affiliations. (c) (i) Open Access This article is licensed under a Creative Commons Attribution 4.0 International License, which permits use, sharing, adaptation, distribution and reproduction in any medium or format, as long as you give appropriate credit to the original author(s) and the source, provide a link to the Creative Commons license, and indicate if changes were made. The images or other third party material in this article are included in the article's Creative Commons license, unless indicated otherwise in a credit line to the material. If material is not included in the article's Creative Commons license and your intended use is not permitted by statutory regulation or exceeds the permitted use, you will need to obtain permission directly from the copyright holder. To view a copy of this license, visit http://creativecommons.org/ licenses/by/4.0/.

(C) The Author(s) 2021 